\title{
Sickle cell anemia in the Boqueirão kilombo community, Bahia, Brazil
}

Anemia falciforme na comunidade quilombola Boqueirão, Bahia, Brasil

\author{
C.R. Dantas, R.A.A. Silva ${ }^{1}$; Studant Group ${ }^{1 \dagger}$; M.M. Amorim ${ }^{1}$; T.B. Figueiredo ${ }^{1}$; \\ R.S. Gestinari ${ }^{2}$; L. Tomazi ${ }^{1 *}$. \\ ${ }^{1}$ Nome do Departamento, Universidade Federal da Bahia, Campus Anísio Teixeira, 45000-000, Vitória da \\ Conquista-Ba, Brasil \\ ${ }_{2}^{2}$ Departamento de Ensino de Graduação, Universidade Federal do Rio de Janeiro, Campus Macaé, 27930-560, \\ Macaé - Rj, Brasil
}

${ }^{\dagger}$ Loureiro, Silvia O.; Bonfim, Deivison S.; Moreira, Alcinete da Silva; Rodrigues-Neto, Alfredo J. A.; Brito, Laís F.; Ribeiro, Jéssica S.; Mendonça, Samir A.; Rodrigues, Lucas O.; Silva, Jaciara M.; Trindade, Manoela R.; Souza, Alex S.; Silveira, Karine C.; Araújo, Suerda P. F.; Dórea, Rafael S. D. M.; Moura, Luciana R.

*laizetomazi@yahoo.com.br

(Recebido em 16 de janeiro de 2016; aceito em 08 de agosto de 2016)

\begin{abstract}
Sickle cell anemia (SCA) is the most common monogenic hereditary disease in Brazil. The North and Northeastern regions of Brazil concentrate a large number of outstanding African ancestry communities, denominated kilombo. The aim of this study was to make a survey of SCA cases in the Boqueirão Kilombo community, situated in Bahia semi-arid region. 467 individuals were interviewed. Individuals $(n=100)$ who replied positively for the occurrence of jaundice, and family history of sickle cell anemia were pre-selected to undergo the diagnostic exam for sickle cell anemia and included in the Group 1. The others individuals $(\mathrm{n}=367)$ were included in the Group 2. Blood samples evaluation of Group 1 showed the following hemoglobin genotypes: HbAA in 65 individuals, HbSS in 3 individuals and HbAS in 29 individuals, $\mathrm{HbAF}$ in 1 individual and $\mathrm{HbAC}$ in 2 individuals. One of the individuals with SCA and all the heterozygotes for the mutated allele $\mathrm{S}$ did not know that they had the mutation. The survey data demonstrate the need for health assistance directed towards these special communities.

Key words: Anemia, Kilombo, Sickle.
\end{abstract}

A anemia falciforme (AF) é a doença hereditária monogênica mais comum no Brasil. As regiões Norte e Nordeste do Brasil concentram um grande número de comunidades com descendência africana, denominadas quilombos. O objetivo deste estudo foi realizar um levantamento dos casos de AF na comunidade quilombola do Boqueirão, situado na região semiárida da Bahia. 467 indivíduos foram entrevistados. Indivíduos $(\mathrm{n}=100)$ que responderam positivamente para a ocorrência de icterícia, e história familiar de anemia falciforme, foram pré-selecionados para realizar o exame diagnóstico para anemia falciforme e incluídos no Grupo 1. Os outros indivíduos $(\mathrm{n}=367)$ foram incluídos no Grupo 2. As amostras de sangue de avaliação do Grupo 1 mostraram genótipos de hemoglobina: HbAA em 65 indivíduos, HbSS em 3 indivíduos e HbAS em 29 indivíduos, HbAF em um indivíduo e HbAC em 2 indivíduos. Um dos indivíduos com $\mathrm{AF}$ e todos os heterozigotos para o alelo $\mathrm{S}$ mutado não sabiam que possuíam a mutação. Os dados da pesquisa demonstram a necessidade de assistência à saúde dirigida para essas comunidades especiais.

Palavras-chave: Anemia, Quilombo, Falciforme.

\section{INTRODUCTION}

Approximately 276,000 new cases of sickle cell anemia are detected annually worldwide [1]. Sickle cell anemia (SCA) is the most common monogenic hereditary disease in Brazil and the best known of the hereditary alterations in man [2]. Individuals with SCA present a hemoglobinopathy characterized by red blood cells rigidity, compromised tissue perfusion and infarction. Chronic hemolysis is related to jaundice, diminished bioavailability of nitric oxide (NO), oxidative stress and endothelial activation [3,4]. Dysfunctional immune response predisposes patients with this hemoglobinopathy to severe infections. Immune system 
abnormalities include impediments in splenic clearance ability, defective complement fixation, dysfunction in responses mediated by $\operatorname{IgG}$ and $\mathrm{IgM}$ and problems related to opsonization [5].

It is believed that the muted $\mathrm{HbS}$ allele, which leads to sickle cell anemia, appeared in Africa. Some authors have reported higher survival of heterozygous individuals with mutated alleles in regions riddled with malaria, which would have led to $\mathrm{HbS}$ allele frequency in the Africa population, and consequently, in Afrodescendant individuals.

Historically, sickle cell anemia has been associated with high childhood mortality [6]. Mortality may be reduced with early attendance, which demands that people should be informed about disease existence and how to identify it [7]. In countries in which neonatal triage for hemoglobinopathies was instituted, a reduction from $40 \%$ to $10 \%$ in mortality due to pneumococcic infections, and general mortality from $8 \%$ to $1.8 \%$ has been demonstrated [8].

Many slaves were brought from Africa to Brazil and were distributed throughout almost all regions of the country. The ethnic origin of the Brazilian population is heterogeneous. Many of the slaves brought mutated forms of the hemoglobin gene. In the State of Bahia there is a NagoYoruba-speaking people influence, directly connected with Africans coming from the Benin region [9]. In contrast, the other regions of Brazil received large influxes of slaves brought from the Congo and Angola. Furthermore, Bahia went through different official periods of black slave traffic [10].

The North and Northeastern regions of Brazil concentrate a large number of communities of outstanding African ancestry, denominated kilombo communities. Estimates have shown that in Brazil there are around two million persons living in 743 communities of this type, and that $70 \%$ of these are located in the Northeastern region. In Vitória da Conquista - BA there are around 40 remainders of kilombos [11] situated in the semi-arid region.

Different researches have studied both the clinical and molecular characteristics of sickle cell anemia in Salvador-BA $[12,13]$. These studies have pointed out the importance of surveying new cases of hematologic alterations in order to be able to contribute to the increased survival of persons with the disease, reducing hospitalizations and expenditures attributed to patients that present sickle cell anemia care [13]. Nevertheless, few studies on sickle cell anemia have been conducted with an approach to the kilombo communities in the State of Bahia. Due to historical questions, these communities are located in geographic locations to which access is difficult. The inhabitants of kilombos have direct family connections with many slaves originating from black slave traffic. Kilombo inhabitants have a low level of schooling, and difficulty of access to specialized health services. The aim of this study was to make a survey of sickle cell anemia cases in the Boqueirão kilombo community, situated in the semi-arid region of Bahia, located 50 $\mathrm{Km}$ from the urban center, in the rural zone of the Vitória da Conquista municipality.

\section{MATERIAL AND METHODS}

\subsection{VOLUNTEERS SELECTION AND SAMPLE COLLECTION}

A questionnaire was applied to 467 Boqueirão Kilombo community residents, situated in the District of José Gonçalves in the municipality of Vitória da Conquista - BA, Brazil. In this study, all community residents, who agreed to participate in the study, were included after signing a Term of Free and Informed Consent (TFIC). The project was approved by the Research Ethics Committee (CEP/UESB Protocol No. 067/2009). The questionnaire was composed of 84 questions, 25 of which were related to signs and symptoms of anemia, and asked about current or previous presence of the following: jaundice, pneumonia, cough with secretion, pain (head, abdominal, muscular, bone, joint), ulcers, hospitalizations, blood transfusions and cases of sickle cell anemia in the family.

All the individuals who replied positively for the occurrence of jaundice, and family history of sickle cell anemia were pre-selected to undergo the diagnostic exam for sickle cell anemia. In the triage, individuals who responded positively for 3 or more signs that might be related to SCA were also included. No random sampling was performed with the objective of benefiting the largest number of individuals with hemoglobinopathies, by means of diagnosis. One 
hundred individuals from the community had a $10 \mathrm{~mL}$ sample of peripheral blood collected in heparinized tubes for hematological evaluations. These 100 individuals composed the Group 1. And the remaining 367 individuals (that not had responded positively to at least three signs and symptoms of anemia falciforme) composed the study Group 2.

\subsection{HEMATOLOGIC ANALYSIS AND HEMOGLOBIN PROFILE IN THE STUDIED POPULATION}

The hemoglobin profiles of the population group were evaluated by protein electrophoresis [14]. Red blood cells were lysed and proteins obtained, separated by size, in a cellulose membrane. A reference protein was run to determine the globin genotypes of samples.

Hemograms were performed to detect morphological and quantitative alterations in the evaluated cell populations [15]. The cells and hematimetric profiles of individuals were evaluated with the use of an automatic cell counter. Blood smears were taken, stained with Giemsa, and cell morphology was evaluated by optical microscopy.

The exam reports were personally delivered to the individuals investigated, with a copy to the community health unit. In cases of positive diagnosis, patients were referred for treatment, follow-up and genetic counseling for sickle cell anemia.

\subsection{STATISTICAL ANALYSIS}

Statistical evaluation of the data was performed using the Fish test for frequency analysis, and Kruskal-Wallis for observing statistical differences between the studied groups. All evaluations were performed by the Graphpad 5.0 program, using a 95\% confidence interval (CI). All values whose $\mathrm{p}<0.05$ were considered significant. 


\section{RESULTS AND DISCUSSION}

\subsection{RESIDENTS CHARACTERIZATION POINTED OUT BY INQUIRY}

For the effects of comparison, inquiry results were divided into two groups: (Group 1) constituted only of individuals who responded positively for jaundice, cases of SCA in the family or three simultaneous manifestations normally presented by patients with falciform disease $(n=100)$ and (Group 2) composed of individuals who did not present positivity for the recently pointed out aspects $(n=376)$.

Groups 1 and 2 were similarly constituted as regards genders and age-ranges, with the majority being constituted of the female gender (60\% of Group 1 and $54 \%$ of Group 2), and having a similar percentage of children and adults (0-12 years: $42 \%$ Group 1 and 32\% Group 2; 13-59 years: 53\% Group 1 and 58\% Group 2; and age $\geq 60$ years: 5\% Group 1 and 10\% Group 2) (Table 1).

In addition to the inclusion factors, the individuals in Group 1 presented other signs and symptoms with significantly higher percentages than the individuals of Group 2, these being: pneumonia (17\% in Group 1 and $4.3 \%$ in Group 2, p<0.01), cough with secretion (23\% in Group 1 and $5.1 \%$ in Group 2, p<0.01), abdominal pain (24\% in Group 1 and $11,1 \%$ in Group 2, $\mathrm{p}<0.01)$, ulcers on lower limbs (15\% in Group 1 and $6.8 \%$ in Group 2, $\mathrm{p}<0.05)$. Blood transfusions were also reported more times in Group 1 than Group 2 (15\% in Group 1 and $0.01 \%$ Group 2, $\mathrm{p}<0.01$ ) (Table 2).

Other clinical manifestations, however, did not differ between the two groups evaluated: Muscle pain (12\% in Group 1 and $11.1 \%$ in Group 2), bone pains (16\% in Group 1 and $12.8 \%$ in Group 2) and joint pains (15\% in Group 1 and 11.4\% in Group 2). The report of hospitalization was also similar between the Groups (32\% in Group 1 and 21.5\% in Group 2).

Table I-Demographic characteristics of the sample

\begin{tabular}{lcc}
\hline & $\begin{array}{c}\text { Group 2 } \\
\mathbf{n = 3 6 7}(\boldsymbol{\%})\end{array}$ & $\begin{array}{c}\text { Group 1 } \\
\mathbf{n = 1 0 0}(\boldsymbol{\%})\end{array}$ \\
\hline Genders & 54 & 60 \\
Female gender & & \\
Age-ranges & 42 & 32 \\
0-12 years & 53 & 58 \\
13- 59 years & 5 & 10 \\
$\geq 60$ years & 53 & \\
\hline
\end{tabular}

Data obtained from the questionnaire applied to 467 residents of the

“Comunidade Quilombola Boqueirão" community. 
Table II - Presence of Signs and Symptoms related to Sickle Cell Anemia

\begin{tabular}{lcccc}
\hline & $\begin{array}{c}\text { Group } \mathbf{2} \\
\mathbf{n = 3 6 7}(\boldsymbol{\%})\end{array}$ & $\begin{array}{c}\text { Group 1 } \\
\mathbf{n = 1 0 0}(\boldsymbol{\%})\end{array}$ & $\mathbf{p}$ value & ODD \\
\hline Jaundice & - & 20.0 & - & $\mathbf{\%}$ \\
Cases of SCA in the family & - & 60.0 & - & - \\
Pneumonia & 4.3 & 17.0 & $<0.01$ & 4.3 \\
Cough with secretion & 5.1 & 23.0 & $<0.01$ & 5.1 \\
Abdominal Pain & 11.1 & 24.0 & $<0.01$ & 2.3 \\
Muscle Pain & 11.1 & 12.0 & $>0.05$ & 1.1 \\
Bone Pain & 12.8 & 16.0 & $>0.05$ & 1.2 \\
Joint Pain & 11.4 & 15.0 & $>0.05$ & 1.3 \\
Ulcers on lower limbs & 6.8 & 15.0 & $<0.05$ & 2.3 \\
Hospitalizations & 21.5 & 32.0 & $>0.05$ & 1.5 \\
Blood Transfusions & 0.0 & 15.0 & $<0.01$ & 107.7 \\
\hline
\end{tabular}

Data obtained from the questionnaire applied to 467 residents of the "Comunidade Quilombola Boqueirão" community. The individuals were divided into two groups: (1) constituted only of individuals who responded positively for jaundice, cases of SCA in the family or three simultaneous manifestations normally presented by patients with falciform disease $(n=100)$ and (2) composed of individuals who did not present positivity for at least three of the recently mentioned aspects $(n=376)$. Fish Test, values with $p<0.05$ were considered statistically significant.

\subsection{HEMOGLOBIN GENOTYPES IDENTIFICATION IN TRIAGED INDIVIDUALS}

Blood samples evaluation of individuals from Boqueirão, by protein electrophoresis showed the following hemoglobin genotypes: HbAA (normal hemoglobin) in 65 individuals, HbSS (sickle cell anemia) in 3 individuals and HbAS (falcemic trace) in 29 individuals, HbAF (normal and fetal hemoglobin in new born) in 1 individual and $\mathrm{HbAC}$ (C trace haemoglobin) in 2 individuals (Figure 1). Of the genotyped individuals 35\% had mutated globins; of these 29\% with falcemic trace and $3 \%$ with sickle cell anemia. 


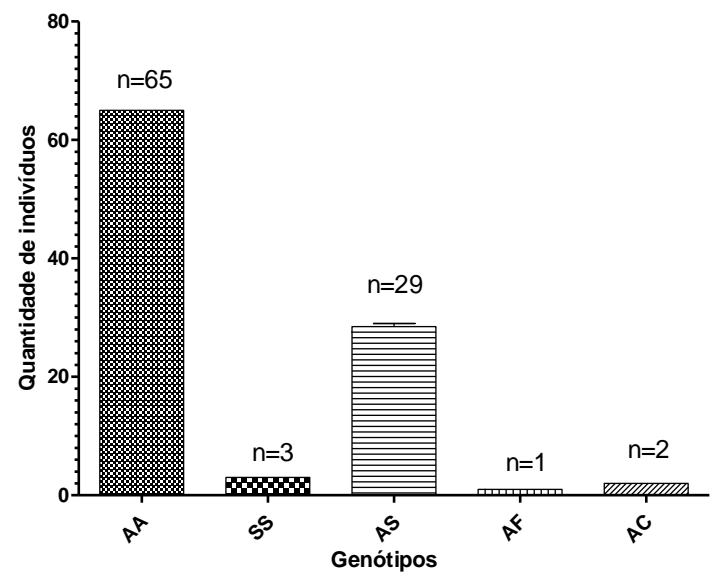

Figure 1- Hemoglobin Genotypes Distribution in Boqueirão - BA. Blood samples of individuals in Group 1 ( $n=100)$ of the kilombo community were collected and evaluated by protein electrophoresis. AA - Normal Hemoglobin; SS Falciform Hemoglobin; AS - Falciform Trace Hemoglobin (heterozygote); AF - Normal and Fetal Hemoglobin in New Born; AC - C trace Hemoglobin (heterozygote). Of the 100 individuals who underwent the exam, $61 \%$ were women; of these $42 \%$ were children (up to 12 years of age), two of these being under the age of 1 year.

\subsection{HEMATIMETRIC INDICES EVALUATION OF GENOTYPED INDIVIDUALS}

As regards the individuals hematologic profile in Group 1 for diagnosing hemoglobinopathies, the results of the study are shown in Table 3. The data reaffirmed that when individuals with sickle cell anemia (genotype SS) were compared with the Groups with genotype AA, they presented a reduced quantity of red blood cells $\left(2.45 \pm 0.1 \mathrm{milllion} / \mathrm{mm}^{3}\right.$, $\mathrm{p}<0.05)$, lower hematocrit value $(20.33 \pm 2.1 \%, \mathrm{p}<0.05)$, less hemoglobin $(7.2 \pm 0.7 \mathrm{~g} / \mathrm{dL}$, $\mathrm{p}<0.05)$ and an increase in the number of leukocytes $\left(18,466.7 \pm 4921.7\right.$ total $\left./ \mathrm{mm}^{3}, \mathrm{p}<0.05\right)$. In the present study, no significant hematologic differences were observed when the other genotypes were compared among them (AA, AS, AF and AC). 
Table III - Hematologic Profiles of Residents - Boqueirão, BA

\begin{tabular}{|c|c|c|c|c|c|}
\hline Genotypes & $\begin{array}{c}\text { AA } \\
n=65\end{array}$ & $\begin{array}{c}\text { AS } \\
n=29\end{array}$ & $\begin{array}{c}\mathrm{SS} \\
\mathrm{n}=\mathbf{3}\end{array}$ & $\begin{array}{c}\mathrm{AF} \\
\mathrm{n}=1\end{array}$ & $\begin{array}{l}\mathrm{AC} \\
\mathrm{n}=2\end{array}$ \\
\hline $\begin{array}{l}\text { Hemocytes } \\
\left(\text { million } / \mathrm{mm}^{3}\right)\end{array}$ & $4.8 \pm 0.5$ & $4.9 \pm 0.4$ & $2.4 \pm 0.1(*)$ & 4.2 & $5.0 \pm 0.3$ \\
\hline Hematocrit (\%) & $39.7 \pm 3.9$ & $39.8 \pm 3.9$ & $20.3 \pm 2.1(*)$ & 32.0 & $38.0 \pm 2.8$ \\
\hline $\begin{array}{l}\text { Hemoglobin } \\
(\mathrm{g} / \mathrm{dL})\end{array}$ & $13.1 \pm 1.4$ & $13.1 \pm 1.3$ & $7.2 \pm 0.7(*)$ & 10.6 & $12.6 \pm 1.0$ \\
\hline RDW & $13.7 \pm 1.5$ & $14.6 \pm 2.2$ & $22.9 \pm 3.1$ & 14.9 & $15.5 \pm 0.4$ \\
\hline $\mathrm{MCHC}(\mathrm{g} / \mathrm{dL})$ & $33.1 \pm 0.9$ & $32.9 \pm 0.8$ & $35.3 \pm 0.6$ & 33.0 & $34.0 \pm 1.4$ \\
\hline $\mathrm{MCH}(\rho g)$ & $27.7 \pm 2.6$ & $26.5 \pm 2.2$ & $29.7 \pm 3.2$ & 25.0 & $25.5 \pm 0.7$ \\
\hline Total & & & & & \\
\hline $\begin{array}{l}\text { Leukocytes } \\
/ \mathrm{mm}^{3}\end{array}$ & $7,067.7 \pm 2,463.9$ & $7,951.7 \pm 4271.6$ & $18,466.7 \pm 4,921.7(*)$ & $8,600.0$ & $6,400.0 \pm 707.1$ \\
\hline Platelets $/ \mathrm{mm}^{3}$ & $\begin{array}{c}274,784.6 \pm \\
94,859.5\end{array}$ & $\begin{array}{c}321,965.5 \pm \\
141,002.9\end{array}$ & $331,000.0 \pm 49,960.0$ & $412,000.0$ & $208,000.0 \pm 1414.2$ \\
\hline
\end{tabular}

Data obtained for individuals belonging to Group 1, are pointed out in the form of means and standard deviation.

RDW: Red Cell Distribution Width; MCHC: mean corpuscular hemoglobin concentration; MCH: mean corpuscular hemoglobin. $(*)$ p $<0.05$, Kruskal-Wallis, when genotype AA group was compared with genotype SS group.

\section{DISCUSSION}

At present SCA is a disease with high prevalence in Brazil, particularly due to historical questions surround its colonization, with emphasis on the contribution of the African population. The relevant African ancestry present in the North and Northeastern regions partly justifies the high incidence of this hemoglobinopathy in these regions $[11,16]$. In spite of the high incidence of this hemoglobinopathy in the above-mentioned regions, few studies have been conducted with the goal of identifying the cases present in isolated communities of African origin in the State of Bahia.

In the present report was observed that individuals who participated in the study, 1:16 persons presented falciform trace (HbAS) and 1:156 persons presented sickle cell anemia (HbSS). The HbAF genotype was found in one newborn $(\mathrm{RN})$, due to the high quantity of hemoglobin $\mathrm{F}$ up to 6 months of life [17]. Subjects with $\mathrm{C}$ trace (HbAC) are asymptomatic, nevertheless, the relevance of this genotype in cases of genetic counseling is to prevent homozygosis $\mathrm{HbCC}$, which causes a symptomatic disease denominated hemoglobinopathy $\mathrm{C}$ [14]. 
When comparing the results obtained in the present study with those described in the literature, one observes that the prevalence of falciform trace is similar, however, the prevalence of sickle cell anemia is higher in the studied community. Nevertheless, it is necessary to take into consideration that the choice of individuals to undergo the diagnostic exam in the present study was not made randomly, but was directed by means of triage. This fact may have overestimated the values found in the present study.

Studies on populations resident in kilombos have also evidenced the association between sickle cell disease, ethnic composition of the population, and slave migration as factors of outstanding importance for understanding the presence of falciform trace in Brazil [18]. The results of the present study corroborate the high number of sickle cell anemia in the black population.

In 2004, Pedrosa and collaborators [19] conducted a survey of the distribution of allele $\mathrm{HbS}$ in 24 remaining kilombo communities, distributed among five Brazilian regions. The results showed that the frequency of this allele ranged from zero in communities from Pará and Rio Grande do Sul, to $13 \%$, in a community in Bahia. Considering all the remaining kilombos studied, the mean frequency of this allele was $3.7 \%$, well below the $8.6 \%$ observed in the African countries from which the majority of slaves came.

It has been reported that the frequency of $\mathrm{HbS}$ may vary considerably in the same geographic region, even in the same state in communities in Bahia. In this State, the frequency of this allele ranges from $0.9 \%$ to $13 \%$. This data reflects the fact that these communities, although they share African ancestry, differ in their foundation and miscegenation histories over the course of time. Consequently, the prevalence of the $\mathrm{HbS}$ allele in these populations is also diverse [19].

The Boqueirão community has water tanks, a dam as water supply, and infrequent local medical visits. The lack of medical assistance directed towards chronic diseases and those particular to the black population, associated with various clinical manifestations of sickle cell anemia, have led to late diagnosis of this pathology. The delay in diagnosis is accompanied by the morbidity of the patient with sickle cell anemia or falcemic trace, in addition to the lack of genetic counseling in family planning by patients.

Among the characteristics of sickle cell anemia there is clinical variability, ranging from patients with innumerable complications and frequent hospitalizations through to asymptomatic patients. According to Fry [20], the clinical manifestations of this pathology are chronic anemia accompanied by osteoarticular and abdominal pains, infections and pulmonary infarcts, retarded growth and sexual maturation, strokes and chronic compromise of multiple organs and systems, such as the circulatory, renal, ocular and dermal systems. Some of these complications do not reduce the patient's life expectancy, although they may considerably compromise the quality of life.

Among the individuals with sickle cell anemia, 100\% responded to the inquiry, affirming that they presented repeated infections, and $66.7 \%$ affirmed that they frequently presented fever (data not shown). Severe infections, especially by Streptococcus pneumoniae, Haemophilus influenzae, Escherichia coli, Streptococcus aureus, among others are found in patients with sickle cell anemia [21]. Infections are the main cause of death in early childhood. This fact points out the need for early diagnosis accompanied by prophylaxis. The use of prophylactic measures such as antipneumococcic vaccines and antibiotic therapy drastically reduce sudden death in children with sickle cell anemia [22].

The development of jaundice is associated with an increase in indirect bilirubin, resulting from the lower survival of red blood cells [22,23]. In the present study this clinical manifestation is pointed out by $20 \%$ of the individuals who underwent protein electrophoresis. Of the individuals with sickle cell anemia, $33.3 \%$ presented discrete polychromatophilia, and all had poikylocytosis with a large quantity of drepanocytes (Table 3). Hemoglobin S (HbS), in concentrations lower than $50 \%$ in the erythrocytes, do not crystallize at the oxygen tensions in vivo, except in eventualities of intense anoxemia [24]. In this context, it is important to point out that one of the individuals with sickle cell anemia $(n=3)$ and all the heterozygots for the mutated allele $S(n=29)$ did not know that they had the disease. Normally the hemogram of individuals with sickle cells anemia shows anemia varying between discrete and accentuated, since hemoglobin $(\mathrm{Hb})$ may be between 6 and $9.5 \mathrm{~g} / \mathrm{dL}$ [25]. 


\section{CONCLUSION}

Lastly, the data of the present study point out a high incidence of sickle cell anemia, falcemic trace and other hemoglobinopathies in another community of African descent located in the Northeastern region. Hematologic alterations were demonstrated in patients with hemoglobinopathies. This study, for the first time, describes an evaluation of sickle cell anemia in the Boqueirão community. The survey data once more demonstrate the need for greater health assistance directed towards special communities with a history of social marginalization and poor provision of health services.

\section{ACKNOWLEDGMENTS}

We are thankful to Brazilian MEC/Sesu by financial support.

\section{REFERÊNCIAS BIBLIOGRÁFICAS}

1. Modell B, Darlison M. Global epidemiology of haemoglobin disorders and derived service indicators. Bull World Healthy Organ. 2008;86:480-6.

2. Silla LMR. Doença falciforme: um grave e desconhecido problema de saúde pública no Brasil. J Pedriat. 1999;75:145-6.

3. Kaul DK, Liu XD, Fabry ME, Nagel RL. Impaired nitric oxide mediated vasodilation in transgenic sickle mouse. Am J Physiol Heart Circ Physiol. 2000;278:H1799-H1806.

4. Zorca S, Freeman L, Hildeshein M, Allen D, Remaley AT, Taylor JG, et al. Lipid levels in sickle-cell disease associated with haemolitic severity, vascular dysfunction and pulmonary hypertension. $\mathrm{Br} \mathbf{J}$ Haematol. 2010;149:436-45.

5. Battersby AJ, Knox-Macaulay HHM, Carrol ED. Susceptibility to invasive bacterial infections in children with sickle cell disease. Pediatr Blood Câncer. 2010;55:401-6.

6. Shaffer TJ, Lorey F, Cunningham GC, Klump C, Vinchnsky E, Lubin B. Newborn screening for sickle cell disease: 4 years of experience from California's newborn screening program. J Pediatr Hematol Oncol. 1996;18:36-41.

7. Diniz D, Guedes C. Anemia falciforme: Um problema nosso. Uma abordagem bioética sobre a nova genética. Cad Saúde Pública. 2003;19(6):1761-70.

8. Vinchinsky E, Hurst D, Early A, Kleman K, Lubin B. Newborn screening for sickle cell disease: effect on mortality. Pediatrics. 1988;81:749-55.

9. Verger P. Flux et Reflux de la traite des nègres entre le golf de Benin et Bahia de Todos os Santos. Paris: Mounton Press; 1968.

10. Gonçalves MS, Bomfim GC, Maciel E, et al. $\beta S$ - Haplotypes in sickle cell anemia patients from Salvador, Bahia, Northeastern Brazil. Braz J Med Biol Res. 2003;36:1283-8.

11. FUNDAÇÃO CULTURAL PALMARES. Brasília: Ministério da Cultura, [cited 2008 Jun 21]. Available from: http://www.palmares.gov.br.

12. Lyra IM, Gonçalves MG, Braga JAP, Gesteira MF, Carvalho MH, Saad STO, et al. Clinical, hematological, and molecular characterization of sickle cell anemia pediatric patients from two different cities in Brazil. Cad Saúde Pública. 2005;21:1287-90.

13. Adorno EV, Couto FD, Neto JPM, Rego M, Reis MG, Gonçalves MS. Hemoglobinopathies in newborns from Salvador, Bahia, Northeast Brazil. Cad Saúde Pública. 2005;21(1):292-8.

14. Weatherall DJ, Clegg JB. The thalassemia syndromes. 3rd ed. Oxford: Blackwell; 1981.

15. Bonini-Domingos CR. Prevenção das hemoglobinopatias no Brasil: diversidade genética e metodologia laboratorial [Tese de Doutorado em Ciências Biológicas]. São José do Rio Preto: Instituto de Biociências, Letras e Ciências Exatas, Universidade Estadual Paulista; 1993.

16. Galiza Neto GC, Pitombeira MS, Vieira HF, Vieira MLC, Farias DAB. Análise dos haplótipos do gene da BS-globina no Ceará. J Bras Pat Med Lab. 2005;41:315-21.

17. Pinheiro LS, Gonçalves RP, Tomé CAS, Alcântara AEE, Marques ARC, da Silva MM. Prevalência de hemoglobina S em recém-nascidos de Fortaleza: importância da investigação neonatal. Rev Bras Ginecol Obstet. 2006;28:122-5.

18. Auricchio M, Vicente J, Meyer D, Netto R. Frequency and origins of hemoglobin S mutation in African-derived Brazilian populations. Human Biol. 2007;79:667-77. 
19. Pedrosa MAF, Ferreira LB, Oliveira SF. Anemia falciforme em antigos quilombos. Ciência Hoje 2004;36: 84-5.

20. Fry PH. O significado da anemia falciforme no contexto da "política racial" do governo Brasileiro 1995-2004. História, Ciências, Saúde - Manguinhos. 2005;12:347-70.

21. Kizito ME, Mworozi E, Ndugwa, C, Serjeant GR. Bacteraemia in homozygous sickle cell disease in Africa: is pneumococcal prophylaxis justified? Arch Dis Child. 2007;92:21-3.

22. Zago MA, Costa FF. O significado da anemia falciforme no contexto da 'política racial' do governo brasileiro Hereditary hemoglobin disorders in Brazil. Trans R Soc Trop Med Hyg. 1985;79:385-8.

23. Nóbrega CG, Machado MA, Nóbrega JCA. Colelitíase associada à anemia falciforme na infância / Cholelithiasis related to sickle cell disease in childhood. Rev bras ciênc saúde. 2001;5:85-8.

24. Failace R. Hemograma, Manual de Interpretação. 4 th ed. Porto Alegre: Artmed; 2003.

25. Santos MNN, Bezerra MAC, Costa R, Bezerra I, Melo FCBC, Araújo AS, et al. Anemia falciforme com e sem interação alfa-talassêmica: perfil laboratorial da casuística do ambulatório de triagem neonatal do Hospital Hemope. In: XX Congresso Nacional Brasileiro de Hematologia e Hemotarapia; 2004, São Paulo. Anais da Revista Brasileira de Hematologia e Hemoterapia, 2004. 26. p. 2-2. 